\title{
鉄塔組立作業の安全対策に関する 労㗢衛生学的研究
}

\author{
等々力達也*
}

\section{AN INDUSTRIAL HYGIENIC STUDY ON THE SAFETY COUNTERMEASURES FOR THE IRON TOWER CONSTRUCTION WORK}

\author{
Tatsuya TODOROKI $\dagger$
}

We have continuously been studying on the occupational health conditions of the tower construction workers, and have already pointed out that their working conditions are severe.

This time, I observed that their heart rate clearly decreased by using an automatic elevator which was made by our suggestion for the tower construction work, and further studied on the worker's heart beat situation which would be affected with psychogenic stress caused by work at high places. The results obtained are as follows:

1. In the case of using the automatic elevator, increase of the heart rate was not remarkable, and consequently, their working burden was lightened as compared with the customary method, which uses the step-bolt for ascending and descending the tower.

2. Using an elevator in the tower construction work has to be valued highly on the safety control for work at high places, and this kind of the elevator has to be introduced in such work in the future.

3. Observations were made, on the heart rate variation caused by continuous psychogenic stress by work at a place as high as 65 meters. But further, observations are thought to be necessary.

\section{I. 緒言}

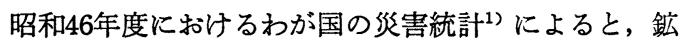
山を除く全産業において，唒落を原因とする休業 8 日以 上の死傷数の割合は, 全死傷数の $10.8 \%$ を占めている が，これが，死亡者の割合となると， $19.5 \%$ に飛躍す る. とくに, 建設業においては, 全体の災害死亡数 2,323 人のらち, 約 $30 \%$ ○のが陮落を原因とするもの で, 依然として, 災害死亡原因のトップを占めている.

また，このような䖎落による死亡災害は，昭和36年度 を 100 とした場合, 昭和 45 年度は 107 であって, 最近に 至って潮増の傾向にある．以上のように，塗落を原因と する災害の防止は, いまだに, 安全管理上の重要な課題

* 琉球大学保健学部保健管理学教室 昭和49年 1 月 30 日受付

† Department of Health Administration, College of Health Science, University of the Ryukyus Received for publication January 30, 1974

\section{と考えられる.}

ところで，䜃落事故に限らず，作業者の行動に基因し ておこる, いわゆる行動災害について, 最近心理学的に はもちろん, 行動科学的なさまざまな検討が活発に行な われている2 5). しかしながら，むちろん労衝衛生学的 なとらえ方も試みられてはいるものの ${ }^{6)}$, 直接的に墜落 事故に結びつく高所作業についての，この方面からの研 究は，いまだ多いとはいえない。

われわれは, 昭和 40 年以来, ほとんどの作業を高所で 行なら, 送電線用の鉄塔組立作業を中心として, 高所作 業に関する一連の労衝衛生学的な検討を試み”), その作 業の労働量が著しく多いことを指摘してきた.今回は, さらにステップボルトによる鉄荅の昇降時と, われわれ の指摘にもとついて新たに用意された，自動エレベータ 一の試用による昇降時の両者から, 鉄塔作業に要する生 理的負担の相違と, 鉄荅上の休秘時と, 地上休憩時とを 比較し, 作業する場所が高所であるがための精神的緊張 
状態を検討しょうと試み，三，三の知見を得たので報告 する.

\section{II. 調 查方 法}

\section{1. 調查対象鉄塔}

栃木県芳賀郡益子町の市街地より東南約 $1.5 \mathrm{~km}$ の丘 "陵部の山頂にある, 東京電力福島幹線增設工事のうち, 古河電工第18工区現場 J $24, K 4$ 鉄塔での組立て作業を 調查の対象とした. 完成時の塔頂高 $80 \mathrm{~m}$. 作業は塔頂部 の組立て作業中であった.

\section{2. 調查月日および天候}

調査は昭和 47 年 8 月 8,9 日の両日にわたり行なっ た. 天候は両日とも晴, ほとんど無風, 気温はほ湆 $28^{\circ} \mathrm{C}$ であった。

\section{3. 調查対象者}

この現場で働いていた鉄塔組立工のうち, 主として塔 上で作業するもの 6 名を選んた。

\section{4. 調查項目}

今回の調查も，われわれが過去 4 回にわたって行なっ てきた，鉄塔工事に関する一連の調查と同様に，被検者 個々の身体的状況と, 実際の作菜時の生理的な傾向とに ついて調查を行なった。

個々の身体的状況については, 被検者らの飯場におい て簡単にできる項目として, 既往歴およびあらかじめ記 入させた CMI を中心とした問讋, 現症をとらえるため の聴打触㖣, 血圧測定, 検尿として糖, 蛋白, ウロビリ ノーゲン, 四肢運動器系および運動機能検查等について 調査した。

作業時の調查は, 今回もハートレイトテレメーター (NEC 製) より得られる心搏数の経時的変化を中心とし て調査した。すなわち，作柴者の心藏部の上下につけた
電極端子によってとらえられる, 心臟収縮時電位差を単 一棘波として, 作業者の腰につけた小型送信機より発信 させ,これを地上の受信記録計の $5 \mathrm{~mm} / \mathrm{sec}$ の速さの記 録紙の上にとらえて分析に用いた。

心搏数のとらえ方としては, 1 時点の前 10 秒の栜数 と, 後 10 秒の韩数, 計 20 秒間の合計棘数を 3 倍して 1 分 間值の心搏数とした. 経時的に10秒間隔の心搏数の变化 を求めた場合にも同様に, 前後 20 秒間の棘数より求め た. したがって，10秒間隔で示された心搏数の変動は常 に, 前後10秒間值が重複して数穴られていることとな る.

\section{III. 調 査 成 績}

Table 1 は, 被検者 6 名の身体的状況を示したもので ある、表に示されたとおり, 被検者の健康状態は総体的 に良好である. CMI に拈いては, 深町开型が 2 人いる が，われわれの過去に打ける同種作業者の成績とくらべ て大差はないと考えられる，運動機能も同様に差異は涩 められず，今回の被検者らの身体的状況には, 特異な傾 向はなかったと考えられる。

Fig. 1 は, 被検者 C.T. について, 従来行なわれて いるステップボルトによる, 塔の昇降時の心搏数の増加 を, 安静時のそれと比較して，何\%増加したかを経時的 に示したものである. 図中の数字およびローマ字は, そ のときの被検者の状態を示したものである.

図によると, 昇塔時, はじめの $20 \mathrm{~m}$ の高さまでは, 心搏の增加がはなはだ急激であるが，それ以降は一定の 高い水準を保っている. 図中数字の 5 以降は, 増加率が やや低下しているが, ここからは, 被検者はステップボ ルトではなくて，塔中に備えられた鉄梯子を利用しての ぼっている。

Table 1. Physical condition of the workers.

\begin{tabular}{|c|c|c|c|c|c|c|c|c|c|c|c|c|}
\hline \multirow{2}{*}{ Name } & \multirow{2}{*}{ Age } & \multirow{2}{*}{$\begin{array}{l}\text { Experi- } \\
\text { ence } \\
\text { (year) }\end{array}$} & \multirow{2}{*}{ Weight } & \multirow{2}{*}{ Height } & \multirow{2}{*}{ Anamnesis } & \multirow{2}{*}{$\begin{array}{l}\text { Status } \\
\left(\begin{array}{l}\text { Pre- } \\
\text { sent }\end{array}\right)\end{array}$} & \multirow{2}{*}{ CMI } & \multirow{2}{*}{\begin{tabular}{l}
\multicolumn{1}{c|}{ Blood } \\
Pressure \\
Rest. Pulse \\
Freq.
\end{tabular}} & \multicolumn{3}{|c|}{ Urine } & \multirow{2}{*}{$\begin{array}{l}\text { Athletic } \\
\text { Function }\end{array}$} \\
\hline & & & & & & & & & Sugar & $\begin{array}{r}\text { Pro- } \\
\text { tein }\end{array}$ & $\begin{array}{l}\text { Urobili- } \\
\text { nogen }\end{array}$ & \\
\hline M. S. & 27 & 5.0 & 70.0 & 172 & naught & good & III & $160-48$ & - & - & - & $\begin{array}{l}\text { rather } \\
\text { good }\end{array}$ \\
\hline H. T. & 45 & 17.0 & 56.5 & 160 & naught & good & I & $124-70$ & - & - & - & $\begin{array}{l}\text { rather } \\
\text { poor }\end{array}$ \\
\hline $\mathrm{Y} \cdot \mathrm{N}$. & 39 & 20.0 & 56.0 & 161 & $\begin{array}{l}\text { before } 5 \mathrm{y} \text {. } \\
\text { Femur } \\
\text { Fract. }\end{array}$ & good & I & $126-82$ & - & - & - & average \\
\hline N. A. & 24 & 1.5 & 62.0 & 166 & naught & good & III & $\frac{104-76}{96}$ & - & - & 一 & $\begin{array}{l}\text { rather } \\
\text { poor }\end{array}$ \\
\hline c. T. & 24 & 1. 0 & 59.0 & 162 & naught & good & I & $130-86$ & - & - & - & above \\
\hline A. K. & 18 & 1.5 & 57.0 & 167 & naught & good & I & $114-60$ & - & - & - & $\begin{array}{l}\text { rather } \\
\text { good }\end{array}$ \\
\hline
\end{tabular}




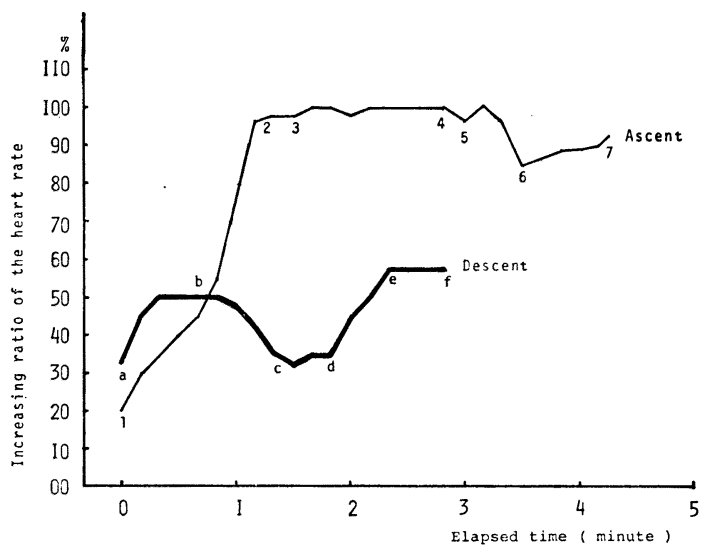

Fig. 1. Heart rate variation in case of the stepbolt. (C.T.)

Ascending ;

1. starting, 2. at $20 \mathrm{~m}$ altitude, 3. $1^{\prime} 30^{\prime \prime}$ passing after starting, 4. resting for $15^{\prime \prime}$ on the low iron arm, 5 . starting again by the ladder, 6. arriving at the middle iron arm, $55 \mathrm{~m}$ altitude, 7. arriving at the upper iron arm, $65 \mathrm{~m}$ altitude.

Descending ;

a. starting ( $65 \mathrm{~m}$ altitude), b. arriving at the middle iron arm, c. arriving at the low iron arm, d. starting again for the low iron arm, e. descending at $20 \mathrm{~m}$ altitude, f. coming down on the ground.

降塔時に要した時間は同じ $65 \mathrm{~m}$ の昇塔時間より短 く, しかも心搏の増加率も少ない. しかし, 地上に近つ くにしたがって, やや増加する傾向にある.

Fig. 2 は, 被検者 M.S. について, 前図と同様にス テップボルトを利用したときの, 昇降時の心搏の増加の 傾向をみたものである.

昇塔開始の直後の心搏数の急激な増加の傾向は, 前図 の被検者 C.T. の場合よりさらに急激である. 以後の一 定化した増加水準に打いてもさらに高水準である. 1 分 間の休賏による心搏増加率曲線の谷がみうけられ, 昇塔 再開と同時に，再び曲線の急上昇がみられる.なお，被 検者 M.S. はすべてステップボルトのみにて昇塔し, 昇 塔の高さは C.T.より低く, 約 $58 \mathrm{~m}$ である.

降塔時は，約 $70 \mathrm{~m}$ のところより下降した．降塔時の 傾向も多少の波を形成しているが，ほぼ C.T.の場合と 大差なく，同じように地上に近づくにしたがって心搏数 の増加が認められる. もちろん, 昇塔時にくらべて心搏 数の増加は著しく少ない.

同じステップボルトによる昇降例として，C.T. と M.S. の両人の心搏数の增加率を比較すると, 両者の間

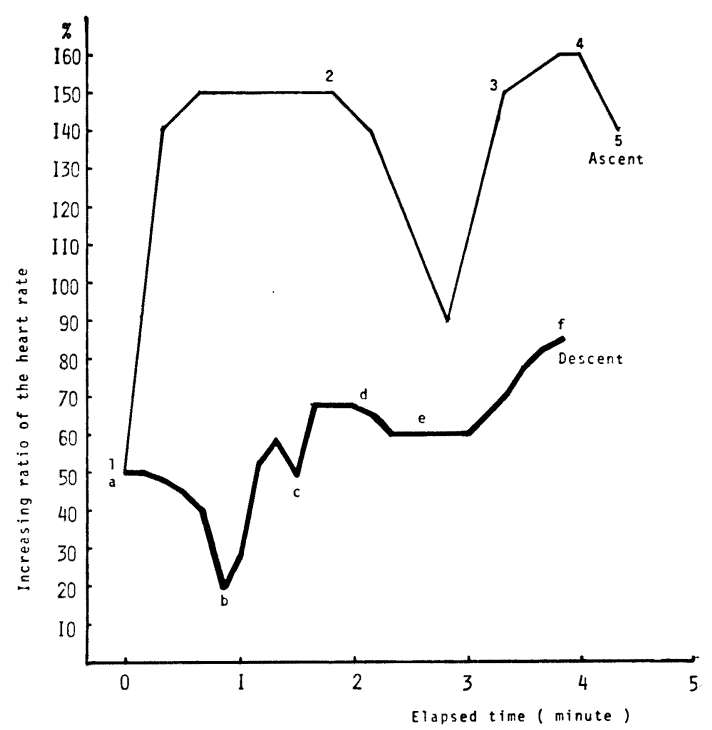

Fig. 2. Heart rate variation in case of the stepbolt (M.S.)

Ascending ;

1. starting, 2. arriving at the landing place (30 $\mathrm{m}$ altitude), and $1 \mathrm{~min}$ resting, 3. arriving at the low iron arm, 4 . arriving at the middle iron arm, 5. arriving at the working place, $3 \mathrm{~m}$ altitude, from the middle iron arm.

Descending ;

a. starting (70 $\mathrm{m}$ altitude), b. arriving at the upper iron arm, c. arriving at the middle iron arm, d. arriving at the low iron arm, e. descending at $30 \mathrm{~m}$ altitude, f. coming down on the ground.

に顕著な差のあることが判明する. すなわち，昇塔時に おいて，C.T. では最高で $100 \%$ の増加であるが, M.S. では $150 \%$ から $160 \%$ を示している. 降塔時において も，とくに地上に近づくにしたがって，両者の差がわか りきってくる. いずれの場合も C.T.より M.S. のほう が，心搏数の増加が著しいことが指摘される.

昇塔時における，途中の休愳の影響としては，わずか に15秒間休んた C.T. の場合には曲線上にその効果をほ とんど認めがたいが， 1 分間休んだ M.S. の例では，休 鄎の効果と考えられる，增加曲線上の谷が認められる.

次に，自動エレベーターを利用した例として，Fig. 3 は被検者 H.T. について心搏数の変化を示したものであ る.

$72 \mathrm{~m}$ の高さにのぼるのに，ほぼ 3 分間かかっている が，このときのェレベータ一の上昇速度は正規速度の約 2 倍である. この場合の昇塔時の心搏数の变化は, 上昇 につれて心搏数は減少し, 最後にやや増加している.下 降時は $50 \mathrm{~m}$ のところから正規速度でほぼ 1 分30秒で地 


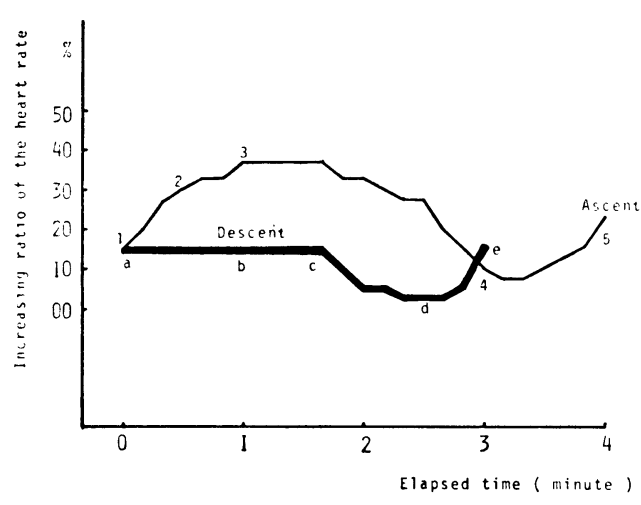

Fig. 3. Heart rate variation in case of the elevator. (H.T.)

Ascending ;

1. walking to the elevator from the resting place, 2 . getting on the elevator, 3 . start of ascending by the elevator, 4. $2 \mathrm{~min}$ after start, 5 . getting off the elevator (72 $\mathrm{m}$ altitude).

Descending ;

a. getting on the elevator (50 $\mathrm{m}$ altitude), b. start the engine movement, c. start of descending, d. 1 min after start of descending, e. coming down on the ground.

上に到着しているが，心搏曲線は昇塔時と同じスプーン 形を示している. また, 昇塔時と下降時の心搏数の増加 率にはほとんど差がない。

Fig. 4 は Fig. 2 と同一被検者である M.S. につい て，同じくェレベーターを使用させたときの成績であ る.この場合の界塔時は，エレベーターにさらにもら一 人の作業者を同乗させ, 正規速度で上昇させた例で, 70 mの上昇に約 5 分 30 秒を要している. しかし, この例に 拈ける, 心搏增加率は多少の波はあるが, 前例の H.T. の場合と大差なく, 同様に最後において上昇し, その上 昇率は著しい。

降塔時は正規速度で下降しているが，心搏数の変化は 少なく, やはり前例に類似しているが, 全般に増加率の 水準が高い.

Fig. 3, Fig. 4 から自動エレベータ一の上昇時の速度 の差による影罄は, 被検者が違らことなどにより, 今回 ははっきりとした点を指摘できない。

しかし，ここでたいせつなことは，Fig. 1, Fig. 2 と

Fig. 3, Fig. 4 を比較することによって，ステップボル ト利用時による昇降にくらべて，自動エレベーター利用 時が，いかに心搏数の増加が少なくてすむかという点 が，明瞭に確認できることである.

Fig. 5 は, 被検者 N.A. をステップボルトで昇塔さ

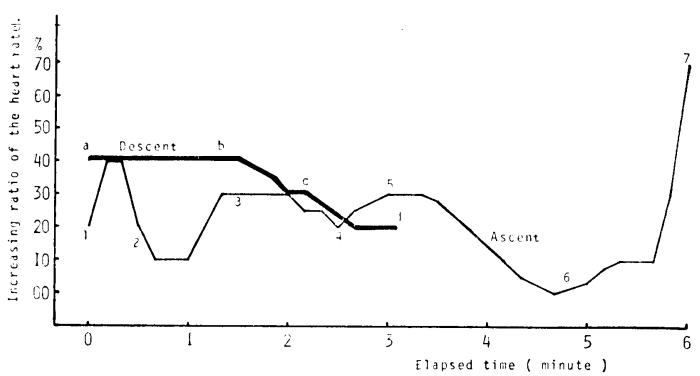

Fig. 4. Heart rate variation in case of the elevator. (M.S.)

Ascending ;

1. walking to the elevator from the resting place, 2. start of ascending by the elevator, 3. $1 \mathrm{~min}$ after start, 4. 2 min after start, 5 . ascending at $30 \mathrm{~m}$ altitude, 6 . ascending at $60 \mathrm{~m}$ altitude, 7. arriving at the upper iron $\operatorname{arm}$ (70 $\mathrm{m}$ altitude).

Descending ;

a. start of descending by the elevator $(70 \mathrm{~m}$ altitude), b. descending at $40 \mathrm{~m}$ altitude, c. descending at $20 \mathrm{~m}$ altitude, d. coming down on the ground.

せたあと，鉄塔から約 $8 \mathrm{~m}$ はなれた送電線上にまたが らせて休顋させ， C.T.については，はじめステップボ ルトで昇塔し，途中から鉄梯子を利用して昇塔し，鉄塔 最上部に近いところにあるプラットホームに腰を拈ろさ せ，ともにできるだけ楽にして休ませたときの，心搏数 の増加率を休憩開始時点より経時的にとらえた曲線 (tw) と, これらの被検者が, 同じくステップボルトで 地上におり立ち，鉄塔から約 $20 \mathrm{~m}$ はなれた休秝地点 で，腰を执ろして休ませたときの心搏曲線（gr）とを比 較した図である.なお，鉄塔上の休㞛地点の高さは，両 人とも地上よりほぼ $65 \mathrm{~m}$ で，作業に必要な命づなをは じめ諸作業用具はいずれの場合も装着させた。 また，天 候に恵まれ，塔上での風による影響はほとんどなかった と考えられる.

この図から, 被検者 N.A.の例では, 塔上, 地上の両 曲線の経時的変化に大差なく，わずかに 4 分後におい て, 地上での曲線が塔上のそれより低水準で移行してい る. 被検者 C.T. においては, 塔上での休憩開始時点の 水準がすでに地上のそれより高く，このへだたりは，経 時的に多少縮まっているものの, 10 分経過後において も, 地上ではすでに安静時心搏数にもどっているが，依 然として約 $10 \%$ の高水準を示している. しかし, 両人 とも，塔上であれ，地上であれ休䤄効果はよく示され， 時間とともに心搏増加率は急激に低下している. 


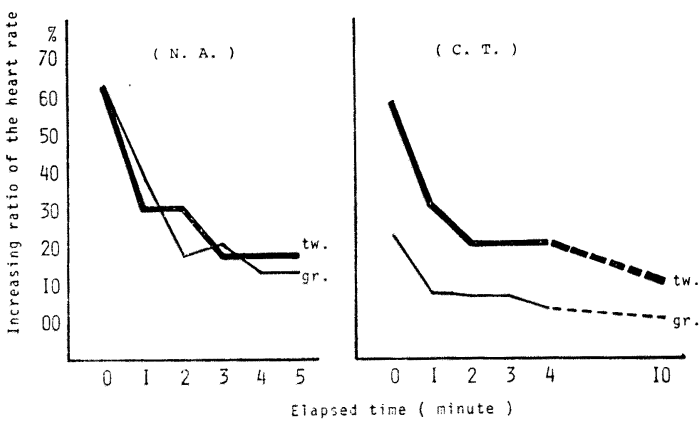

Fig. 5. Comparison of the heart rate variation between relaxation on the tower and the ground.

\section{IV. 考察}

われわれは，すでに過去 4 回にわたり，送電線鉄荅組 立作業について種々観察し7)，ステップボルトによる鉄 塔昇降に際しての，心搏変化のパターンをとらえてき た。

すなわち，組立工のほとんどが，昇塔時には，はじめ の 10 数 $\mathrm{m}$ から $20 \mathrm{~m}$ くらいの高さまでに登る速さは実 に速く，ほとんど一気にのぼってしまうが，それ以降 は，自己の呼吸にあわせながらのぼるようになり，のぼ る速さも持そくなる.Fig. 1 の図中数字 2 以降が，一定 の高水準で保たれ，それ以上増加しないのは，前述のよ らな，作業者自身によるコントロールに起因すると考え られ，このような心搏増加のパターンは, われわれの過 去の成績と一致する.

また, 降塔時に, 地上に近づくにしたがって, 心搏数 の増加がみられるのは, やはり,これら作業者が一般に 地上に近づくにしたがって，下降速度が著しく速くなる ためと考えられ，これも従来のパターンと一致する。す なわち,この鉄塔の組立に従事している作業者も, 彼等に 共通したパターンによって，昇降しているといえよう．

Fig. 1 の図中数字 5 以降の心搏增加がやや低くなって いるが，これは昇塔方法がステップボルトから梯子にか わった影響と考えられるが，この場合に，梯子のほうが 本当に生理的負担が軽いものなのか, あるいは, 労作の 強さとしてはステップボルトと変わりはないが，不安定 なステップボルトにくらべて安定性がよいための, 心理 的影響によるものなのか, 鉄塔組立時の昇塔手段として の優劣をきわめたいところであるが，今後の課題といえ よう.

ところで, Fig. 1, Fig. 2 にみられる, 被検者 C.T. 之 M.S. の心搏増加水準の差は, 個人の体質的差か, 経 験によるものか，あるいは運動量が根本的に違うのか，
いろいろと考えられる．体質的には，M.S.は体格がよ く, やや肥満している. C.T. は比較的バランスがとれ た体格である. 運動機能はやや C.T.のほらが良いが， この点が心搏数に，これほどの影響を与えるものではな いと考えられる，たた，心搏数が一定の高水準に達する 時間は, C.T. はほぼ70秒, M.S. は40 秒で, 昇塔開始 から一気にのぼる高さが同じとすれば，昇塔速度に大き な差があるようで，経験，年跉などからして， M.S.の ほうがのぼり方が速いのであろう．とすれば，M.S.の ほうが高水準の増加があって当然と考えられるが, 後述 のエレベーター下降時に, M.S. が他の被検者より高水 準を示していることと考えあわせると, たんに運動量の 問題だけでは説明されえないようである.

しかし, 本研究の目的にそった要点として, 今回もス テップボルトによる鉄塔の昇降には, 以前指摘したと同 様な, 著しい心搏数の增加がみられる。

次にエレベーターを試用して昇降した場合の心搏数の 変化であるが, Fig. 3, Fig. 4 では, 昇塔のため, 休憩 地点よりエレベーターまで歩く場合に, 心搏数の增加が みられるが, エレベーターが上昇しはじめるにしたがっ て, 心搏数が徐々に隇少している.このことは, ェレべ 一ターに搭乗して上昇している間は，あたかも休覟をし ているのと同じことと考えられる.しかも，この場合， 被検者 H.T. と M.S. とに増加率の水準に差がほとん ど認められない.しかし，エレベーターが塔頂部に近づ き, やがて到着する時点では, 両者とも心搏数がふえる が，これは明らかに，エレベーターから足場の覀い鉄塔 に渡るときの精神的緊張感に由来するものと考えられ る. とくに，M.S. においてこの傾向が強く，このこと は，ステップボルトでの年塔時に，M.S. が他の被検者 とくらべて, 全般に心搏数の增加水準が高かったことと 軌を一にしているのかもしれない，また，エレベーター による下降時においても, M.S. のほうが H.T. にくら ベて，全般に高水準であるが，いずれにせよ，この点の 個人的差違についての理由ははっきりとはつかみえな い.

以上述べてきたなかから，明瞭なことは，ステップボ ルトによる昇降にくらべ，エレベーターでは昇降時の心 搏增加が著しく減少することで，したがって，エレベー ターを使用することによって，昇降時の作業者の生理的 負担を著しく軽減することがでさることである.このこ とは，昇降の市とにつづく，作業負担をも軽減すること が想像できる.

送電線の鉄塔組立工事は一つの代表的高所 作 業であ り, 労動省の災害発生モデル8)に述べられているところ 
Table 2. Specifications of the elevator developed for the work of iron tower construction and inspection for maintenance.

\begin{tabular}{l|c}
\multicolumn{1}{c|}{ Model } & SVE-170 \\
\hline Carrying capacity & $170 \mathrm{~kg}$ \\
\hline Number of passengers & 2 \\
\hline Driving method & $\begin{array}{l}\text { Fuji-Robin-Engine } \\
1.8 \mathrm{PS} / 4500 \mathrm{rpm} \\
2 \text { driving wheel paralleled } \\
\text { Pin-Rack Mode }\end{array}$ \\
\hline Ascending speed & $12 \sim 14 \mathrm{~m} / \mathrm{min}$ \\
\hline Descending speed & $18 \sim 20 \mathrm{~m} / \mathrm{min}$ \\
\hline $\begin{array}{l}\text { Emergency descending } \\
\text { speed }\end{array}$ & $15-22 \mathrm{~m} / \mathrm{min}$ \\
\hline Size of the cage & $1000 \times 600 \times(1000)$ \\
\hline Operation & Hand \& auto-worked \\
\hline Safety devices & Fourfold \\
\hline Weight of the cage & $120 \mathrm{~kg}$ \\
\hline Overrun stoppers & Upper and lower ends \\
\hline
\end{tabular}

の「陮落・転落」，「飛来・落下」，あるいは鉄材等によ る「激突され」などの事故が，いっでも拉こりらるよら な, 非常に高い災害のポテンシャリティを，その作業の 特質としてもっている，さらに，頻回な昇り降り，狭湓 な足場とそれに伴う不自然な姿勢といった作業条件む加 わって，作業者側はさらにいちだんと強い，物的条件に 由来する束縛をしいられている.

すなわち，このよらな㷋害のポテンシャリティの高い 作業には，人間側の条件を目標とする対策よりも，1に も2にも物的環境の絶対的安全化をめざすべきであるこ とが, 多くの安全専門家達によって,くり返し指摘され ている ${ }^{9 \sim 13)}$.この意味において，今回のように，エレべ ーターを試用してみたことは，その効果が明らかとなっ た現在，安全対策上高く評価されるべきことと考えられ る.

以上のように，この種のェレベーターを導入したこと は，高所作業としての鉄塔組立工事の物的環境の改善と して，著しく役だったことは明らかであるが，ただ残念 なことは，現在のエレベーターの界降速度がおそく，と もすると作業者に敬遠されることである．したがって， この点の改良を急ぐとともに，なんらかの使用の義務づ けが必要であろう。な扰，今回試用したェレベーターの
詳細は，Table 2 に示したとおりである

今までのわれわれの調 査では, 送電線鉄塔組立作業 は, 単純肉体労働としては, かなり強度の強いものであ ると推定することができた．ただし，この作業は地上は るかな高所で行なわれるものであるゆ党，そのための精 神的緊張も無視することはできないと考兄られる。この ことから，特別な精神的緊張を与えないよう，リラック スした状態で, もし鉄塔上と, 地上とで心搏数の変動に 差があるとすれば，鉄塔上，すなわち，高所にいるとい らだけの理由による，持続的な精神㗨張からくる影響が 観察でさるものと考光, その検討も試みた。

その結果については，Fig. 5 に示したと拈りである が，今回は心搏の回復の過程の中で，塔上と地上とでど のような差がみらけられるかを検討した.

まず，塔上の休熄地点に達する過程として，N.」．は ステップボルトで昇塔後, 碍子上を渡って送電線上に出 るため, 命づなの付けかえに時間がかかっていること と，同時に動作も著しく緩慢となり，その間に心搏数の 減少が著しかった．C.T.はステップボルトで昇塔後， 中部アームから上は鉄梯子でのぼり，上部プラットホー ムに到着後ただちに休頽させた。 この間, 多少の心搏数 の減少がみられたが，なおも地上での休㮩開始時より高 水準であった。

被検者 N.A.の成績では, 休想開始時点の心搏增加水 準は，塔上も地上も同じで，時間とともに休㰾効果によ る急激な減少が，ほぼ同じような経過でみられ，4 分後 に至って，地上での水準が塔上のそれを下まわった。し かし，この例は観察時間がわずか 5 分間にすぎず，明確 な差異を指摘できるには至っていないと考兄られる.

C.T.については，休㮩開始時の水準差が，時間ととも にわずかずつ狭ばまりつつ，ともに急激に下向曲線を描 き, 10分後に, 地上での休䕀効果は, 心搏数を安静時の それに回復させているが, 塔上ではいまだに約 $10 \%$ の増 加水準にある. このことから，塔上ではいくぶんかの高 所に由来する緊張の影響がらかがえるようであるが，む ともと休秝開始時において塔上例の心搏增加水準が高か ったための酸素債の影響が，いっをで続いているかが判 然としないことから，早急な結論は出しえないと考えら れる.したがって，この例においても，もっと長時間に わたる観察が必要ではなかったかと考学られる。しか し，組立て作業の最中といら制約の中で，満足したとら え方はできなかったが，この課題については，今後さら に検討を加え，明らかにしたいと考えている.

最後に，このような現場作業の実態をつかむ方法とし て，ハートレートテレメーターはその片鱗をとらえる手 
段として，有効であると考える.

\section{V. 結詇}

われわれは，鉄塔組立作業に関する一連の労衝衛生学 的調査を行なってきたが，今回は自動エレベーターを利 用した場合の, 作業時の心搏数の变化に与える影響と, 高所由来の持続的精神緊張による心搏の状態について観 察し, 次の結論を得た。

1）自動エレベーターを利用した場合，従来のステッ プボルトにくらべ，鉄荅昇降時の心搏数の増加を著しく おさえることができ，作業者の労働負荷を著しく軽減す る.

2) このような作業に自動エレベーターを使用した試 みは，安全管理上高く評価される．今後この種の作業に はぜひ自動エレベーターの導入を考慮すべきである.

3）地上 $65 \mathrm{~m}$ の高所での, 高所由来之考えられる持 続的精神緊張による心搏変動について観察を試みたか， 今後の検討が必要である.

稿をおっえるあたり，本調査にご協力いただいた，古河金属 白土清実氏, 古河電工福田昌之氏，古河電設竹村東虎氏，拈上 び種々ご便宜をはかっていただいた東京電力安全担当諸氏のご 厚情に対しまして深謝いたします。

\section{文献}

1）労働省労働基準局：安全の指標，99-111，中央労働災 害防止協会, 東京, 1973 .

2) 近藤英一郎 : 安全と人間関係，安全，23(6) : 45-50, 1972.

3）井上威恭：安全管理技術の体系化，安全，23(12)：6$11,1972$.

4）岩谷不二男：安全管理技術の体系化，組織面からみた体 系化, 安全, 23(12)：12-16, 1972.

5）市村昭二：人間要因を重視せよ, 安全, $23(10): 6-7$, 1972.

6）森川利彦：災害発生者の身体条件の分析，安全，23(4)： $21-23,1972$.

7）等々力達也, 白土清実 : 高所作業者の健康診断, 労動行 生, $11: 20-24,1970$.

8）労働省：死災害の事故の型および起因物分類，安全, 23(7) : 58-63, 1972.

9）房村信雄：本質安全化による不安全状態の解消, 安全, $23(9): 6-7,1972$.

10) 野原石松：级害ポテンシャルの排除，安全， $24(6): 10$ $-13,1973$.

11）住谷自省：原因分析の考光方，安全， 23(4)：8-12, 1972.

12）森清善行: 注意と行動, 安全, 24(8): 8-11， 1973.

13）安倍北夫：炎害の心理, 安全, $24(8): 21-25,1973$.

14）三和鉄軌: SVE-170 型説明書, 1-5, 東京, 1972 .

15）三和テッキ：自走式鉄塔昇降機説明書， 1-13，東京. 1973. 